\title{
Persuasi dalam Wacana Iklan
}

\author{
Sri Puji Astuti \\ Fakultas Ilmu Budaya Universitas Diponegoro \\ Email: sripujiastuti0116@gmail.com
}

\begin{abstract}
Advertisement is a marketing tool that helps selling goods, providing services, and ideas through certain way in the form of persuasive information. How the persuasion strategy used the advertiser in other to be able to draw attention of potential customers is discussed in this paper. This research data is in the form of advertising discourse. The data used in this study comes from the advertising discourse of online. In the data collection activities used was the observation method or refer method namely listening the use of language in the advertising discourse online. Data was selected according to the research needs. Data were analyzed by using content analysis. The results showed that there were two ways of advertisers persuading prospective customers was persuasion implicitly, and explicitly.
\end{abstract}

Keywords: Advertisement, online, persuasion, implicitly, and explicitly.

\section{Intisari}

Iklan merupakan alat pemasaran yang membantu menjual barang, memberikan layanan, serta gagasan atau ide-ide melalui saluran tertentu dalam bentuk informasi yang persuasif. Bagamanakan strategi persuasi yang digunakan pengiklan agar dapat menarik colon konsumen dibahas dalam makalah ini. Data penelitian ini berupa wacana iklan. Data yang digunakan dalam penelitian ini bersumber dari wacana iklan online. Di dalam kegiatan pengumpulan data digunakan metode observasi atau metode simak yaitu menyimak penggunaan bahasa dalam wacana iklan online. Data dipilih sesuai dengan kebutuhan penelitian. Data dianalisis menggunakan analisis isi. Hasil penelitian menunjukkan bahawa ada dua cara pengiklan mempersuasi calon konsumen yaitu persuasi secara implisit dan persuasi secara eksplisit.

Kata Kunci: iklan, online, persuasi, eksplisit, dan implisit.

\section{Pendahuluan}

Iklan merupakan salah satu bentuk komunikasi untuk memenuhi fungsi pemasaran. Untuk memenuhi fungsi tersebut iklan bukan sekadar memberikan informasi kepada khalayak, tetapi harus mampu membujuk atau mengarahkan khalayak untuk membeli produk. Iklan juga harus dapat mempengaruhi pemilihan dan keputusan pembeli (Jefkins, 1997:15) Menurut Wright (dalam Liliweri 1992:20) iklan merupakan suatu proses komunikasi yang mempunyai kekuatan yang sangat penting sebagai alat pemasaran yang membantu menjual barang, memberikan layanan serta gagasan atau ide-ide melalui saluran tertentu dalam bentuk informasi yang persuasif. 
Untuk mempersuasi calon konsumen pengiklan menggunakan berbagai macam strategi agar apa yang diiklankan dapat menarik calon konsumen. Salah satu cara untuk mempersuasi calon konsumen yaitu mengunakan pilihan kata. Pilihan kata yang kreatif dan tepat akan dapat mempengaruhi pikiran seseorang (Agustrijanto, 2002:159).

Berdasarkan media yang digunakan, iklan terdiri atas iklan media elektronik, iklan media cetak, dan internet. Yang dimaksud iklan media ektronik yaitu iklan yang disampaikan melalui radio, televisi, video dan film. Yang dimaksud iklan media cetak adalah iklan yang disampaikan melalui media seperti surat kabar majalah, tabloid dan sebagainya. Pemilihan media sangat penting karena dengan pemilihan media yang tepat pesan yang disampaikan dapat dipahami khalayak sasaran dengan jelas. Dalam makalah ini dibahas iklan yang menggunakan media internet.

Berdasarkan latar belakang tesebut permasalahan yang akan dibahas dalam makalah ini adalah bagamana cara pengiklan mempersuasi calon konsumen. Adapun tujuan penelitian ini adalah menjelaskan cara mengiklan mempersuasi calon konsumen melalui iklan produk yang ada di internet.

Penelitian ini menggunakan teori persuasi. Persuasi berasal dari kata to persuade yang berarti membujuk atau meyakinkan. Roekomy (1992:2) berpendapat bahwa persuasi adalah suatu kegiatan psikologis dalam usaha mempengaruhi pendapat, sikap, dan tingkah laku seseorang atau orang banyak agar berpendapat, bersikap, dan bertingkah laku seperti yang diharapkan. Wacana ini berisi paparan yang berdaya bujuk atau pun yang berdaya imbau. Persuasi bertolak dari pendirian bahwa pikiran manusia dapat diubah. Jadi wacana ini selalu bertujuan mengubah pikiran orang lain agar menerima dan melakukan sesuatu sesuai yang diinginkan. Untuk mencapai tujuan tersebut perlu diciptakan kesesuaian atau kesepakatan. Sejalan dengan Roekomy, Ekowardono (1998:3) berpendapat wacana persuasi adalah wacana yang menyatakan ajakan, himbauan, harapan, saran, permintaan atau bujukan. Wacana persuasi berorientasi pada waktu sekarang dan waktu yang akan datang. Jadi, wacana ini tidak berorientasi pada waktu lampau.

Djajasudarma (1994:10) berpendapat bahwa tujuan wacana persuasi yaitu untuk mempengaruhi orang lain agar terpikat oleh suatu pendapat yang dikemukakan. Isi wacana ini selalu berusaha untuk memiliki pengikut atau penganut atau paling tidak menyetujui pendapat yang dikemukakannya itu kemudian terdorong untuk melakukan atau mengalaminya. Faktor-faktor yang harus dipertimbangkan dalam komunikasi 
persuasi meliputi kejelasan tujuan, memikirkan secara cermat orang-orang yang dihadapi, serta memilih strategi yang tepat (Kasim, 2011)

Dalam wacana persuasi fakta-fakta yang relevan dan jelas harus diuraikan sedemikian rupa sehingga simpulannya dapat diterima secara meyakinkan. Penulis menghadirkan argumen yang logis melalui penggunaan bahasa. Jadi, dalam wacana persuasi, penggunaan diksi perlu diperhatikan karena diksi sangat berpengaruh terhadap emosi atau perasaan (Stanlay et al. 1988:349).

Agustrijanto (2001:20) berpendapat bahwa kata-kata dalam iklan harus

1. Menggugah artinya wacana iklan harus dapat mencermati kebutuhan konsumen, memberikan solusi, dan memberikan perhatian

2. Informatif artinya kata-kata yang digunakan harus jelas, bersahabat, rinci, komunikatif, dan tidak bertele-tele.

3. Persuasif maksudnya rangkaian kalimatnya membuat konsumen nyaman, senang, dan tentram.

4. Bertenaga gerak maksudnya komposisi kata-katanya membimbing konsumen untuk menghargai waktu selama promosi berlangsung.

5. Memiliki penyelesaian akhir artinya kata-kata yang digunakan harus membantu calon konsumen mendapatkan barang dan jasa secara mudah dan cepat.

\section{Metode Penelitian}

Data penelitian ini berupa penggalan wacana iklan. Data yang digunakan dalam penelitian ini bersumber dari wacana iklan online. Di dalam kegiatan pengumpulan data digunakan metode observasi atau metode simak, yaitu menyimak penggunaan bahasa dalam wacana iklan. Data dipilih sesuai dengan kebutuhan penelitian. Teknik yang digunakan adalah teknik catat. Teknik ini digunakan untuk mencatat data yang telah diamati. Dalam penelitian ini digunakan analisis isi. Analisis isi digunakan karena yang dianalisis adalah isi iklan. Analisis isi adalah sebuah teknik penelitian untuk membuat inferensi-inferensi dengan mengidentifikasi secara sistematis dan objektif karakteristik-karakteristik khusus dalam sebuah teks (Stone dalam Krippendorff 1991:19). Sejalan dengan Stone, Hosti (dalam Moleong 1995:163) berpendapat bahwa analisis isi adalah teknik yang digunakan untuk menarik simpulan melalui usaha menemukan karakteristik pesan dan dilakukan secara objektif dan sistematis. 


\section{Pembahasan}

Berdasarkan hasil penelitian ditemukan cara pengiklan mempersuasi calon konsumen yaitu persuasi secara implisit dan persuasi secara eksplisit.

\section{Persuasi secara implisit}

Persuasi implisit adalah persuasi secara tidak langsung. Pengiklan mempersuasi calon konsumen dengan menggunakan kata-kata seperti yang dapat dilihat dalam contoh berikut ini.

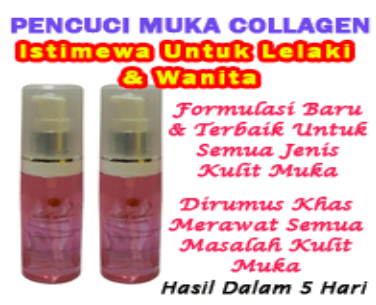

\section{Hjhairul-jb.com}

Iklan sabun pencuci muka colagen di atas mempersuasi calon konsumen dengan cara menunjukkan keunggulan produk, yaitu colagen merupakan sabun cuci muka yang istimewa, yaitu sabun muka yang dapat digunakan pria dan wanita. Biasanya sabun pencuci muka untuk pria dan wanita tidak sama. Di samping itu, dalam iklan ini terdapat kalimat formulasi baru dan terbaik untuk semua jenis kulit muka. Jadi, iklan ini menginformasikan bahwa colagen cocok utnuk semua jenis kulit muka, dan diramu untuk mengatasi semua masalah kulit. Dengan menunjukkan keunggulan produk ini diharapkan calon konsumen tertarik membeli sabun cuci muka colagen.

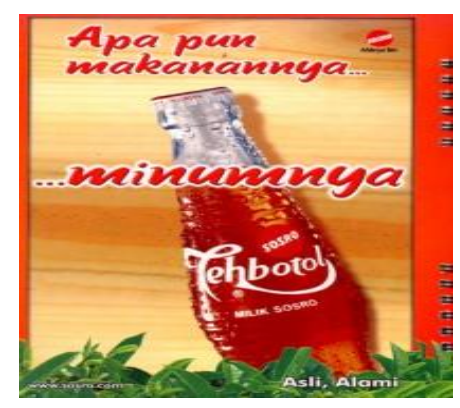

Lisavigiyanti. Ordpress.com

Dalam iklan Tehbotol Sosro terdapat kalimat apapun makanannya minumannya Tehbotol Sosro. Kalimat ini mempersuasi orang secara tidak langsung. Orang selalu mengingat Tehbotol Sosro apa pun yang dimakannya. Pengiklan juga menambahkan 
keterangan bahwa Tehbotol Sosro ini asli dan alami. Dengan membaca iklan ini orang selalu teringat Tehbotol Sosro sebagai pelengkap makanannya.

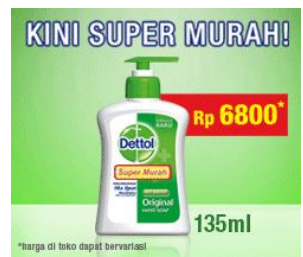

\section{Dkvkita.blogspot.com}

Iklan Dettol mempersuasi calon konsumen secara tidak langsung yaitu dengan cara menonjolkan harga yang dianggap super murah, yaitu Rp 6.800,00. Sayangnya iklan ini tidak memberikan harga yang biasanya. Dalam iklan ini juga dijelaskan bahwa harga di toko dapat bervariasi. Jadi, sebenarnya maksud iklan ini hanya menginformasikan tentang harga dettol yang mengalami penurunan, sehingga dengan iklan ini diarapkan calon konsumen tertarik utuk membeli sabun dettol.

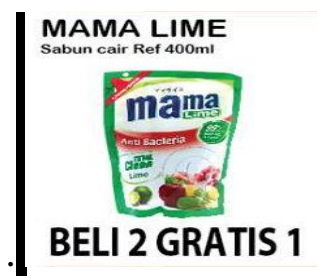

Dalam iklan Mama Lime digunakan kata gratis untuk menarik calon konsumen. Pemakaian satuan lingual beli 2 gratis 1 ini sangat menarik calon konsumen karena adanya faktor harga murah. Jadi, harga tidak seperti biasanya. Pemakaian satuan lingual tersebut diharapkan dapat menarik calon konsumen untuk segera membeli Mama Lime karena biasanya saat promosi seperti itu waktunya sangat terbatas.

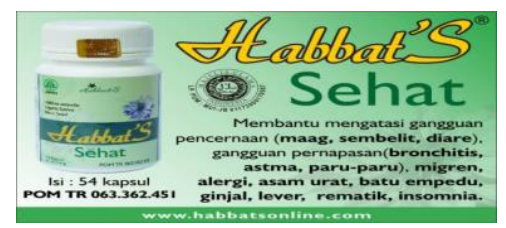

\section{Fjb.kaskus.co.id}

Dalam wacana iklan di atas juga digunakan persuasi implisit karena pengiklan tidak secara langsung menyarankan atau memerintah calon konsumen menggunakan produk. Pengiklan dalam iklan hanya menginformasikan manfaat produk Habbats, isi kemasan, dan no POM TR 063.362.451. Dengan mengetahui manfaat Habbat diharapkan calon konsumen menggunakan produk tersebut. 


\section{Persuasi secara Eksplisit}

Persuasi eksplisit adalah persuasi secara langsung. Artinya pengiklan menyarankan, menyuruh calon konsumen menggunakan produk yang ditawarkan. Biasanya persuasi secara langsung ditandai oleh kalimat perintah. Perhatikan contoh berikut ini.

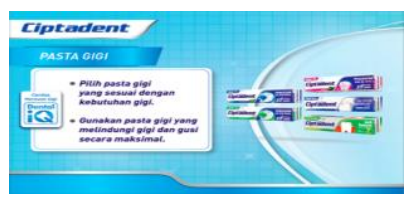

\section{Ciptadent.co.id}

Dalam wacana iklan Ciptadent pengiklan langsung menyarankan calon konsumen memilih pasta gigi yang sesuai dengan kebutuhan gigi. Hal tersebut terdapat dalam kalimat Pilih pasta gigi yang sesuai dengan kebutuhan gigi. Kata pilih digunakan karena memang produk pasta gigi Ciptadent bermacam-macam sehingga calon konsumen diharapkan dapat memilih produk sesuai dengan kebutuhan giginya. Di samping itu dalam wacana iklan tersebut terdapat kalimat gunakan pasta gigi yang melindungi gigi dan gusi secara maksimal. Pengiklan menganjurkan calon konsumen menggunakan pasta gigi yang dapat melindungi gigi dan gusi karena kadang-kadang calon konsumen pada waktu membeli pasta gigi tidak memperhatikan manfaatnya secara detail. Dengan demikian, pengiklan mengharapkan calon konsumen dapat memilih produk yang bagus dan yang sesuai dengan kebutuhan.

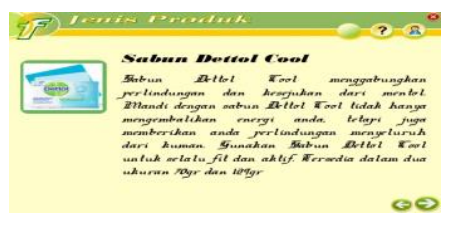

www.slideshare.net

Dalam wacana iklan Sabun Dettol Cool, pengiklan mempersuasi calon konsumen secara eksplisit. Hal tersebut ditandai dengan pemakaian kata Gunakan. Dalam wacana iklan ini sebelum pengiklan menyuruh calon konsumen menggunakan produk pengiklan menjelaskan manfaat produk, yaitu mandi dengan sabun Dettol Cool dapat mengembalikan energi dan melindungi tubuh dari kuman. Di samping itu, iklan tersebut juga menginformasikan ukuran sabun yang tersedia di pasaran, yaitu 70 gr dan 120 gr. Dengan informasi tersebut diharapkan calon konsumen bisa memilih ukuran sabun yang paling cocok, dan pada akhirnya tertarik untuk membeli. 


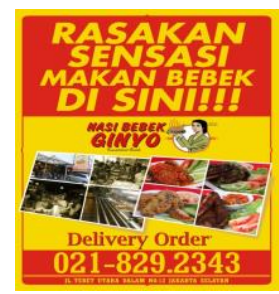

www.bebekginyo.com

Pengiklan dalam iklan Nasi Bebek Ginyo langsung menyuruh calon konsumen untuk merasakan bebek Ginyo. Hal tersebut terdapat dalam kalimat rasakan sensasi makan bebek di sini! Pengiklan selanjutnya menginformasikan nomor telepon dan alamat yang dapat dihubungi seandainya calon konsumen mau memesan produk. Hal tersebut dimaksudkan agar calon konsumen yang tidak mempunyai waktu datang ke lokasi dapat pesan melalui telepon. Makanan yang dipesan bisa diantar. Jadi, iklan tersebut memberi kemudahan calon konsumen yang waktunya sangat terbatas.

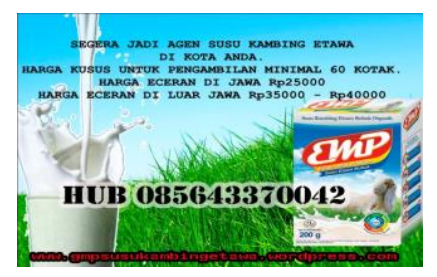

Qmpsusukambingetawa

Pengiklan dalam wacana iklan susu etawa di atas menyuruh calon konsumen untuk menjadi agen susu etawa. Hal tersebut terdapat dalam kalimat segera jadi agen susu etawa di kota Anda. Dalam iklan tersebut pengiklan juga menginformasikan bahwa pembelian minimal 60 kotak akan mendapatkan harga khusus. Lebih lanjut dijelaskan mengenai harga eceran di Jawa Rp/ 25.000,00 dan di luar Jawa Rp. 35.000,00 sampai Rp. 40.000,00. Pengiklan menjelaskan harga-harga tersebut agar calon konsumen tertarik untuk menjadi agen baik di Jawa maupun di luar Jawa.

\section{Simpulan}

Berdasarkan hasil analisis di atas dapat disimpulkan bahwa ada dua cara mempersuasi calon konsumen, yaitu persuasi secara implisit dan persuasi secara eksplisit. Persuasi secara implisit berarti pengiklan tidak langsung menyarankan calon konsumen membeli atau menggunakan produk. Sedangkan persuasi secara eksplisit berarti pengiklan secara langsung menyarankan calon konsumen membeli atau menggunakan produk yang diiklankan. 


\section{Daftar Pustaka}

Agustrijanto. 20001. Copywriting Seni Mengasah Kreativitas dan Memahami Bahasa Iklan. Bandung: PT Remaja Rosdakarya.

Djajasudarma, T Fatimah. 1994. Wacana Pemahaman dan Hubungan Antarunsur. Bandung: PT Eresco.

Ekowardono. B Karno. 1998. "Tata Wacana". Semarang: Proyek Operasi dan Perawatan Fasilitas Institut Keguruan Ilmu Kependidikan.

Jefkins, Frank. 1997. Periklanan. Terjemahan Haris Munandar. Jakarta: Erlangga.

Kasim, Melani. 2011. "Cara Mempengaruhi Orang Lain dengan Menggunakan Metode Persuasif”. Pranala: https://meilanikasim.wordpress.com/2011/02/01/caramempengaruhi-orang-lain-dengan-menggunakan-metode-persuasif/.

Krippendoff, Klaus.1991. Analisis Isi Pengantar Teori dan Metodologi. Penerjemah Farid Wajidi. Jakata: Rajawali Pres.

Liliweri, Alo. 1992. Dasar-Dasar Komunikasi Periklanan. Bandung: PT Citra Aditya Bakti.

Moleong, Lexy. 1995. Metode Penelitian Kualitatif. Bandung: PT Remaja Rosda Karya.

Roekomy. 1992. Dasar-Dasar Persuasi. Bandung: PT Citra Aditya Bakti.

Stanley, Linda C. 1988. Ways to Writing Purpose Task and Pricess. New York: Macmillan Publishinng Company. 